\title{
Uncovered Interest Rate Parity and Investment: A Tripartite Analysis of Nigeria, United States of America and China
}

\author{
Peter $\mathrm{Ubi}^{1} \&$ Ishaku Rimamtanung Nyiputen ${ }^{2}$ \\ ${ }^{1}$ Department of Economics, University of Calabar, Cross River State, Nigeria \\ ${ }^{2}$ Department of Economics, Federal University Wukari, Taraba State, Nigeria \\ Correspondence: Peter Ubi, Department of Economics, University of Calabar, Cross River State, Nigeria.
}

Received: August 26, 2019

Accepted: November 29, 2019

Online Published: March 16, 2020

doi:10.5430/ijfr.v11n2p111

URL: https://doi.org/10.5430/ijfr.v11n2p111

\begin{abstract}
This study comparatively examined the validity of the theory of uncovered interest rate parity (UIP) for Nigeria and United States of America (USA) and for Nigeria and China, using USA and China as anchor countries respectively. The study also examined the impact of the theory (UIP) on investment in Nigeria. Using annual time series data spanning from 1980-2017, the pre-estimation test (Augmented Dickey-Fuller Unit root test) was conducted. Given that the variables were integrated of order one and order zero, Autoregressive Distributed lag bound testing approach (ARDL) and Toda- Yamamoto causality test were employed for analysis. The ARDL result indicates that there is no long run relationship between Nigeria and USA but there is a long run relationship between Nigeria and China. By implication, the theory of UIP does not hold between Nigeria and USA but between Nigeria and China, the theory of UIP holds. Also, the result of Toda-Yamamoto indicates that the theory of UIP positively and significantly impacts on investment in Nigeria. The study recommended that the government should strengthen her economic relationship especially with China so as to encourage more investments by China in Nigeria.
\end{abstract}

Keywords: uncovered, interest, tripartite and investment

JEL: E22 and E43

\section{Introduction}

With increase in trade and globalization, there is an uneven distribution of the costs and benefits. This appears to have aggravated inequalities of wealth and power within and between countries. According to Raffiee (2003), the problems of inequality of wealth and power are caused by the interest rate and exchange rate differentials (theory of uncovered interest rate parity) between countries. Thus, the disparity between exchange rate and interest rate between Nigeria, United States of America and China reveal that Nigeria recorded the highest exchange rate of 305.28 naira per dollar in 2017, while China exchange rate reached its highest pick of 8.35 Yen for a dollar in 1995. However, in 1980 both Nigeria and China recorded the lowest exchange rate values of 0.55 kobo and 1.49 Yen per dollar respectively (World Bank (2018).

Interest rate parity is a no-arbitrage condition representing an equilibrium state under which investors will be indifferent to interest rates available on bank deposits in two countries. The fact that this condition does not always hold, allows for potential opportunities to earn riskless profits from covered interest arbitrage. The Uncovered Interest rate Parity (UIP) is a parity condition stating that the differences in interest rates between two countries are equal to the expected change in exchange rates between the countries' currencies.

The Uncovered Interest Rate Parity assumption has played a vital role in the development of open economies. The covered interest rate parity (CIP) and UIP are important because they can be used in measuring or assessing capital mobility and perfect substitutability of assets and promotion of investment between countries. In addition to that, they can also be used in terms of trade improvement, solving problems of balance of payments disequilibrium etc. If there are no controls in foreign capital movements, capital will move from capital surplus country to capital scarce country due to the fact that interest rate is higher in the latter. Ultimately, interest rate increases in the capital exporting country and falls in the capital importing country. Thus, the verification of UIP in international financial markets would be a joint testing of capital mobility and foreign exchange rate market efficiency between countries (Karahan, 2012), 
Nigeria, China and United States of America (USA) have long been into bilateral trade relationship. The USA is the largest foreign investor in Nigeria and the volume of their investment amounted to $\$ 8.4$ billion in 2012 and decreased to $\$ 8.1$ billion in 2013 and it decreased further in 2014, 2015 as a result of Nigeria's currency restriction after the crash in crude price in international market (U.S Department of State, investment climate statement 2015).United States foreign direct investment concentrated largely in the petroleum/mining and wholesale trade sectors. The United States is the second leading exporter of goods and services in the world and the number one leading importer (U.S Global Leadership Project Report -2012). The USA has always run a trade deficit, mainly due to the dependence on foreign oil to meet its energy needs and high domestic demand for consumer goods produced abroad, however, with the discovery of oil and domestic oil production, the energy gap is closing. China, on the other hand, is the main source of United States imports. But China which is trading partners with United States of America is also a major trading partner with Nigeria (United States Global Leadership Project Report - 2012). The actual terms of trade of Nigeria, China and United States of America are 110.30 index points from 2000-2017, and average of 99.70 index point as at February, 2018 and 98.39 index point as at March, 2018 respectively. The above statistics of 110.30 actual terms of trade of Nigeria for 17 years shows that Nigeria's terms of trade is unfavorable compared to China and United States of America. A prolonged fall or decline in the terms of trade could be seen as a problem because it can lead to low standard of living, lower GDP, lower export revenue and difficulties to pay foreign external debt. This will be a problem for developing economies like Nigeria with high external debt (Kissell, 2006). The disparity in interest rates and exchange rates which might be the cause of unfavorable terms of trade for Nigeria may in turn affect investment decision which can hamper economic growth in the long run.

There had been studies analyzing the validity of UIP by scholars such as Orji, Orji and Ani (2013), Lily et al (2011), Nyugen (2013) and Deebii (2016) with conflicting results. For instance, Deebii (2016) conducted a Panel Data Analysis on the Validity of UIP in Selected African Countries, but the result shows that the theory of UIP holds between Nigeria, Kenya, and Egypt but it does not hold between Botswana and Ghana. The results of the findings were conflicting (that is some findings indicate the validity of the theory in some developing countries while some invalidates the theory between countries). It is on this basis that further empirical investigation is necessary with extended data points to investigate the validity of the theory between a developing country like Nigeria and industrialized countries like China and USA and also examine the impact of the theory on investment in Nigeria. The study attempts to provide answers to the following specific questions :(a.) Does uncovered interest rates parity (UIP) hold between Nigeria and United State of America (USA)? (B). Does UIP hold between Nigeria and China? (C.) Does the theory of UIP have any impact on investment in Nigeria?

\section{Literature Review and Theoretical Issues}

Ferreira (2015) examines variables for Brazil and USA. The paper used a single equation framework and the result of the study showed a strong support for theory of UIP. This implies that the theory of UIP holds between the two countries. Chi-Wei et al (2019) investigated whether covered interest rate parity (CIP) holds for China or not by examining the dynamic link between nominal interest rate differential and nominal exchange rate. The study took into consideration economic transitions and structural changes by applying a time-varying rolling window approach to revisit the dynamic causal relationship. The study discovered that CIP does not hold in China. The study went further to identify some factors that may bring about the CIP deviations to include capital control measures, exchange regime reforms, etc.

In the same vein, Ronald et al (2018) examined uncovered interest rate parity (UIP) and economic uncertainty using a threshold estimation model in six industrialized countries (Canada, United Kingdom, Japan, Europe, United States of America and Switzerland). The study indicated that UIP is more likely to hold under low economic uncertainty periods rather than during high economic uncertainty period. The implication is that arbitrage opportunities are more certain in stable periods and therefore would have a more predictable effect on exchange rate movements.

Dmitry, Vladimir and Sergey (2017) tested and interpreted UIP in Russia and other emerging market economies for the period of 2001 to 2014 using Seemingly Unrelated Regressions Estimates (SURE) and Panel data analysis. The paper shows that UIP holds in Russia better than in other emerging market economies. The study concludes that emerging market economies risk premiums are often constant whereas in Russia, it is almost always volatile

Orji, Orji and Ani (2013) used Ordinary Least Squares to examine whether the theory of UIP holds between Nigeria and USA. The result revealed that the theory of UIP does not hold between Nigeria and USA. Aggarwal (2013) investigated the UIP puzzle in the international market exchange. The paper focused on the theory of UIP from 1992 to 2005 using GARCH model for the United Kingdom and United States .The finding validates the theory of UIP. Omer (2013) tested uncovered interest rate parity using LIBOR rates for the major international currencies from 
2001 to 2008 in United States. The finding suggests that it is important to take the cross section between exchange rate and interest rate. Furthermore, Ray (2012) tested whether the theory of UIP hold in India and the result indicates that the theory of UIP does not hold in India.

Karahan (2012) tested the UIP for Turkey and Tunisia using monthly data between 2002 and 2011. Using Ordinary Least Squares and GACH for the analysis, the result shows that the theory does not hold between turkey and Tunisia. Another work by Lily and Kogid (2011) tested Uncovered Interest Rate Parity between selected developed countries using ARDL. The finding indicates that the theory does not hold between the countries under study. From the received literature, it is obvious that several authors (Orji, Orji and Ani, 2013, Lily and Kogid, 2011, Karahan, 2012, Omar, 2013 and Aggarwal, 2013) have conducted researches on uncovered interest rate parity. However, the findings have been conflicting. Most of the studies conducted on UIP tested the validity of the theory between developed countries rather than the developing countries. Studies such as Lily and Kogid (2011),Karahan (2012),Omar (2013), Aggarwal(2013), have tested the validity of the theory of uncovered interest rate parity in countries of Africa, Asia, and Latin America using very small sample size of 10 or 20 years. This study is unique as it is using an extended data point of 37 years (1980-2017). Also, this study is a deviation from the previous study by Orji, Orji and Ani (2013) that used nominal interest rate as against real interest rate used in this study. This study would as well examine the impact of the theory of uncovered interest rate parity (UIP) on investment.

Theoretically, the theory of capital Flow movement, the Classical Theory of Interest Rate Determination and Accelerator theory of investment are the main theories driving this study.

The theory of capital Flow movement was propounded by the neoclassical school of thought (1965). The theory states that in a two-country world, domestic economy and foreign country or developing country and developed country, other things being equal, a rises in domestic interest rate compared with foreign rate of interest would results in domestic economy taking advantage of higher differentials in returns between the two countries as a result of increase in domestic rate of interest relative to foreign interest rate. Thus, capital flows raise the roles of domestic interest rate and fall the roles of international interest rate.

The Classical Theory of Interest Rate Determination postulates that investment is a function of interest rate was Propounded by Marshall and Fisher (1930). This means that when interest rate is low, investment would be high and vice-versa. Interest rate and investment have an inverse relationship. That is, $\mathrm{I}=\mathrm{f}(\mathrm{r})$ Where: $\mathrm{I}=$ investment, $\mathrm{f}=$ function of, $r=$ interest rate. Economists such as Alfred Marshall, Irvin Fisher and J.B. Clark have different views on interest rate determination. Marshall and Fisher view interest rate from the supply side of capital that is, saving while Clark views interest rate from the demand side; that is investment.

Accelerator theory of investment developed by J.M Clark (1917), postulates that income and consumption rise will result in rise in investment by double. Thus investment is the function of income and consumption.

\section{Model and Data}

The variables used for models (1) and (2) of this study are real interest rate differentials, exchange rate differentials and inflation rate differentials between Nigeria and United States of America and Nigeria and China. Thus, equations (1) and (2) are anchored on the theory of interest rate parity and empirical work by Redeckaite and Sokolovska (2004) while equations (3) and (4) anchored on the classical theory of interest rate determination. It should be noted that the sample size for this analysis is 1980 to 2017 (38 years). The equations (1) and (2) for this study are specified functionally for USA and China as follows:

$$
\text { USNID }=\mathrm{f}(\mathrm{USNEXD}, \mathrm{USNCPID}
$$

Where:

USNID $=$ USA and Nigeria Interest rate differential (a measure of UIP)

USNEXD $=$ United States of America and Nigeria Exchange rate differential

USNCPID = United State of America and Nigeria Consumer Price Index differentials

$$
\text { CHNID }=f(\text { CHNEXD, CHNCPID })
$$

Where:

CHNID $=$ China and Nigeria Interest rate differential (a measure of UIP)

$\mathrm{CHNEXD}=$ China and Nigeria Exchange rate differential

CHNCPID = China and Nigeria Consumer Price Index Differentials 
Equations (3) below is transformed of equation (1)into the econometric form given as follows:

$$
\begin{aligned}
\Delta \operatorname{Ln}(\text { USNID })_{\mathrm{t}}= & \delta_{\mathrm{o}}+\delta_{1} \operatorname{Ln}\left(\mathrm{USNID}_{\mathrm{t}-1}+\delta_{2} \operatorname{Ln}\left(\mathrm{USNEXD}_{\mathrm{t}-1}+\delta_{3} \operatorname{Ln}\left(\mathrm{USNCPID}_{\mathrm{t}-1}\right.\right.\right. \\
& +\sum_{\mathrm{i}-1}^{\mathrm{m}} \gamma 1 \Delta \ln \operatorname{USNID}_{\mathrm{t}-\mathrm{I}}+\sum_{\mathrm{i}-1}^{\mathrm{m}} \theta 2 \Delta \operatorname{LnSNEXD}_{\mathrm{t}-\mathrm{I}} \\
& +\sum_{\mathrm{i}-1}^{\mathrm{m}} \eta 3 \Delta \operatorname{LnUSNCPID}_{\mathrm{t}-1}+\varphi_{1} \mathrm{ECM}_{1 \mathrm{t}-1+\mu_{\mathrm{t}}}
\end{aligned}
$$

Where:

$\delta_{o=}$ the intercept,

$\delta_{1} \delta_{2=}$ coefficient United State and Nigeria interest rate differential and United

$\gamma, \theta, \eta=$ coefficients of United States and Nigeria interest rate differentials, United States and Nigeria exchange rate differentials and United States and Nigeria consumer price index differentials respectively.

$\Delta=$ difference operator,

$\mathrm{m}=$ lag length of the variables

$\varphi 1=$ the Speed of adjustment

$E C M 1_{t-i}$

$\mu_{t}$

USNID $=$ United State and Nigeria interest rate differentials

USNEXD=United State and Nigeria exchange rate differentials

USNCPID $=$ United States and Nigeria consumer price index differentials.

Equation (4) below is the transformation of equation (2) into econometrics form which is used to test the validity of the theory of UIP between China and Nigeria.

$$
\begin{aligned}
\Delta \operatorname{Ln}(\text { CHNID })_{\mathrm{t}}= & \beta_{\mathrm{o}}+\beta_{1} \operatorname{Ln}(\mathrm{CHNID})_{\mathrm{t}-1}+\beta_{2} \operatorname{Ln}\left(\mathrm{CHNEXD}_{\mathrm{t}-1}\right. \\
& +\beta_{3} \operatorname{Ln}(\mathrm{CHNCPD})_{\mathrm{t}-1} \sum_{\mathrm{i}-1}^{\mathrm{m}} \lambda 1 \Delta \mathrm{LnCHNID}_{\mathrm{t}-\mathrm{i}}+\sum_{\mathrm{i}-1}^{\mathrm{m}} \lambda 2 \Delta \operatorname{LnCHNEXD}_{\mathrm{t}-\mathrm{i}} \\
& +\sum_{\mathrm{i}-1}^{\mathrm{m}} \lambda 3 \Delta \operatorname{LnCHNCPID}_{\mathrm{t}-1}+\varphi_{2} \mathrm{ECM}_{2 \mathrm{t}-1+\mathrm{V}_{\mathrm{t}}}
\end{aligned}
$$

Where:

$\beta_{o=}$ the intercept,

$\beta_{l,} \beta_{2=}$ the coefficient of China and Nigeria interest rate differentials and China and Nigeria exchange rate differentials respectively.

$\lambda_{1}, \lambda_{2} \lambda 3=$ coefficients of China and Nigeria interest rate differentials, China and Nigeria exchange rate differentials and China and Nigeria consumer price index differentials

$\Delta$ =difference operator,

$\mathrm{m}=$ lag length of the variables

$\varphi 2=$ the Speed of adjustment

$\mathrm{ECM} 2{ }_{t-i}$

$v_{t=}$ uncorrelated white noise residuals

$\mathrm{CHNID}=$ China and Nigeria interest rate differentials.

$\mathrm{CHNEXD}=$ China and Nigeria exchange rate differentials.

$\mathrm{CHNCPID}=$ china and Nigeria consumer price index differentials.

$\mathrm{H}_{0}: \beta_{0}=\beta_{1}=\beta_{2}=\lambda_{1}=\lambda_{2}=\lambda 3 \quad$ (No long run relationship exist)

In order to achieve the objective of this study, ARDL Bound test and Toda and Yamamoto Causality which is also called the Modified Wald Test (MWALD) method is utilized. ARDL Bound test is aimed at testing whether there is cointegration between the variables under study. This work used quadra-variate VAR $\left(\mathrm{k}+d_{\text {max }}\right)$ model which comprised investment (INV) measured by gross fixed capital formation, Income (measured by GDP), China and Nigeria interest rate differentials (CHNID), as well as United States of America and Nigeria interest rate differentials (USNID) which denote the uncovered interest rate parity (UIP). 
The investment model is anchored on interest rate determination postulated by the classical school of thought. This theory states that investment is dependent on the rate of interest. Investment has an inverse relationship with interest rate. The functional form of the model for America and Nigeria is specified in model 5 and 6 respectively:

$$
\mathrm{INV}=\mathrm{f}(\mathrm{USNID}, \mathrm{Y}, \mathrm{USNCPID})
$$

Where

INV = Investment (measured by gross fixed capital formation) in millions of naira

USNID = United State of America and Nigeria Interest rate differentials

$\mathrm{Y}=$ Nigeria's Income measured by Gross Domestic Product in millions of naira

USNCPID $=$ United States of America and Nigeria consumer price index differentials.

$$
\mathrm{INV}=(\mathrm{CHNID}, \mathrm{Y}, \mathrm{CHNCPID})
$$

Where:

INV = Investment (measured by for gross fixed formation) in millions of naira

CHNID $=$ China and Nigeria Interest Rate differentials

$\mathrm{Y}=$ Income measured by Gross Domestic Product in millions of naira.

CHNCPID = China and Nigeria consumer price index differentials

The equations are transformed into econometrics form for econometric analysis.

$$
\begin{aligned}
\Delta \ln (\mathrm{INV}) t=\partial_{0} & +\partial_{1} \ln (\mathrm{INV})_{\mathrm{t}-1}+\delta_{2} \ln (\text { USNID })_{\mathrm{t}-1}+\delta_{3} \ln (\mathrm{Y})_{\mathrm{t}-1}+\delta_{4} \ln \left(\mathrm{USNCPID}_{\mathrm{t}-1}\right. \\
& +\sum_{\mathrm{i}-1}^{\mathrm{m}} \omega_{1} \Delta \ln \mathrm{INV}_{\mathrm{t}-1}+\sum_{\mathrm{i}-1}^{\mathrm{m}} \omega_{2} \Delta \ln \mathrm{USNID}_{\mathrm{t}-1}+\sum_{\mathrm{i}-1}^{\mathrm{m}} \omega_{3} \Delta \ln _{\mathrm{GDP}} \mathrm{t}_{\mathrm{t}-1} \\
& +\sum_{\mathrm{i}-1}^{\mathrm{m}} \omega_{4} \Delta \ln \mathrm{USNCPID}_{\mathrm{t}-1}+\gamma \mathrm{ECM}_{\mathrm{t}-1}+\varphi_{\mathrm{t}}
\end{aligned}
$$

Where

$\partial_{0}=$ the intercept

$\partial_{1}, \delta_{2}, \delta_{3}, \delta_{4}=$ coefficients of INV, USNID, Y and USNCPID in the long run respectively.

$\omega_{1}, \omega_{2}, \omega_{3}, \omega_{4}=$ coefficients of INV, USNID, Y and USNCPID in the short run respectively.

$\Delta=$ the difference operator,

$\mathrm{m}=$ the lag length of the variables

$\gamma=$ the Speed of adjustment

$\mathrm{ECM}_{t-i}$

$\varphi_{t=}$ uncorrelated white noise residuals

$$
\begin{aligned}
\Delta \ln (\mathrm{INV}) t= & +\alpha_{1} \ln (\mathrm{INV})_{\mathrm{t}-1}+\alpha_{2} \ln (\mathrm{CHNID})_{\mathrm{t}-1}+\alpha_{3} \ln (\mathrm{Y})_{\mathrm{t}-1}+\alpha_{4} \ln (\text { CHNCPID })_{\mathrm{t}-1} \\
& +\sum_{\mathrm{i}-1}^{\mathrm{m}} \delta 1 \Delta \ln \mathrm{INV}_{\mathrm{t}-1}+\sum_{\mathrm{i}-1}^{\mathrm{m}} \delta 2 \Delta \ln _{\mathrm{CHNID}} \mathrm{t}_{\mathrm{t}-1}+\sum_{\mathrm{i}-1}^{\mathrm{m}} \delta 3 \Delta \ln _{\mathrm{GDP}} \mathrm{t}_{\mathrm{t}-1} \\
& +\sum_{\mathrm{i}-1}^{\mathrm{m}} \delta 4 \Delta \ln \mathrm{CHNCPID}_{\mathrm{t}-1}+\tau \mathrm{ECM}_{\mathrm{t}-1}+\pi_{\mathrm{t}}
\end{aligned}
$$

Where

$\alpha_{0}=$ is the intercept

$\alpha_{1}, \alpha_{2}, \alpha_{3}, \alpha_{4}=$ is the coefficients of INV, CHNID, GDP and CHNCPID in the long run respectively.

$\delta 1, \delta 2, \delta 3, \delta 4=$ is the coefficients of INV, CHNID, Y and CHNCPID in the short run respectively.

$\Delta=$ the difference operator,

$\mathrm{m}=$ the lag length of the variables

$\tau=$ the Speed of adjustment

$\mathrm{ECM}_{t-i}$ 
$\pi_{t=}$ uncorrelated white noise residuals

Toda and Yamamoto Granger Causality model specification for all the investment equation which is used to estimate the impact of UIP on Nigeria and China interest rate differential on investment in Nigeria is:

$$
\begin{aligned}
& I N V=\alpha+\sum_{i=1}^{q} \gamma i \operatorname{INV}_{(t-1)}+\sum_{j=q+1}^{q+d \max } \gamma j \operatorname{INV}_{(t-j)}+\sum_{i=1}^{q} \rho i \operatorname{CHNID}_{(t-i)}+\sum_{j=q+1}^{q+d m a x} \rho j \operatorname{CHNID}_{(t-j)} \\
& +\sum_{\mathrm{i}=1}^{\mathrm{q}} \emptyset_{\mathrm{i} \mathrm{Y}_{(\mathrm{t}-\mathrm{i})}}+\sum_{\mathrm{j}=\mathrm{q}+1}^{\mathrm{q}+\mathrm{dmax}} \emptyset_{\mathrm{j} \mathrm{Y}_{(\mathrm{t}-\mathrm{j})}}+\sum_{\mathrm{i}=1}^{\mathrm{q}} \eta \mathrm{iCHNCPID}(\mathrm{t}-\mathrm{i}) \\
& +\sum_{\mathrm{j}=\mathrm{q}+1}^{\mathrm{q}+\mathrm{dmax}} \eta \operatorname{CHNCPID}_{(\mathrm{t}-\mathrm{j})}+\varepsilon_{\mathrm{t} 1} \\
& \operatorname{CHNID}=\beta+\sum_{\mathrm{i}=1}^{\mathrm{q}} \mu \mathrm{i} \operatorname{CHNID}_{(\mathrm{t}-1)}+\sum_{\mathrm{j}=\mathrm{q}+1}^{\mathrm{q}+\mathrm{dmax}} \mu \mathrm{j} \operatorname{CHNID}_{(\mathrm{t}-\mathrm{j})}+\sum_{\mathrm{i}=1}^{\mathrm{q}} \sigma \mathrm{iNNV}(\mathrm{t}-\mathrm{i}) \\
& +\sum_{j=q+1}^{q+d m a x} \sigma j \operatorname{INV}_{(t-j)}+\sum_{i=1}^{q} \varphi \mathrm{i} Y_{(t-i)}+\sum_{j=q+1}^{q+d m a x} \varphi j Y_{(t-j)}+\sum_{i=1}^{q} \delta i \operatorname{CHNCPID}_{(t-i)} \\
& +\sum_{\mathrm{j}=\mathrm{q}+1}^{\mathrm{q}+\mathrm{dmax}} \delta \mathrm{CHNCPID}_{(\mathrm{t}-\mathrm{j})}+\varepsilon_{t 2} \\
& \mathrm{Y}=\Phi+\sum_{\mathrm{i}=1}^{\mathrm{q}} £ i \mathrm{Y}_{(\mathrm{t}-1)}+\sum_{\mathrm{j}=\mathrm{q}+1}^{\mathrm{q}+\mathrm{dmax}} £ j \mathrm{Y}_{(\mathrm{t}-\mathrm{j})}+\sum_{\mathrm{i}=1}^{\mathrm{q}} \mathrm{ji} \mathrm{INV}_{(\mathrm{t}-\mathrm{i})}+\sum_{\mathrm{j}=\mathrm{q}+1}^{\mathrm{q}+\mathrm{dmax}} \mathrm{jj} \operatorname{INV}_{(\mathrm{t}-\mathrm{j})} \\
& +\sum_{\mathrm{i}=1}^{\mathrm{q}} \mathrm{qi} \operatorname{CHNID}_{(\mathrm{t}-\mathrm{i})}+\sum_{\mathrm{j}=\mathrm{q}+1}^{\mathrm{q}+\mathrm{dmax}} \mathrm{qj} \operatorname{CHNID}_{(\mathrm{t}-\mathrm{j})}+\sum_{\mathrm{i}=1}^{\mathrm{q}} \Psi_{\mathrm{i} \operatorname{CHNCPID}_{(\mathrm{t}-\mathrm{i})}} \\
& +\sum_{\mathrm{j}=\mathrm{q}+1}^{\mathrm{q}+\mathrm{dmax}} \Psi \mathrm{j} \operatorname{CHNCPID}_{(\mathrm{t}-\mathrm{j})}+\varepsilon_{\mathrm{t} 4} \\
& \operatorname{CHNCPID}=6+\sum_{\mathrm{i}=1}^{\mathrm{q}} \mathrm{piCHNCPID}_{(\mathrm{t}-1)}+\sum_{\mathrm{j}=\mathrm{q}+1}^{\mathrm{q}+\mathrm{dmax}} \mathrm{pj} \mathrm{CHNCPID}_{(\mathrm{t}-\mathrm{j})}+\sum_{\mathrm{i}=1}^{\mathrm{q}} \mathrm{eiINV}_{(\mathrm{t}-\mathrm{i})} \\
& +\sum_{j=q+1}^{q+d m a x} \rho j \operatorname{INV}_{(t-j)}+\sum_{i=1}^{q} \Theta i \operatorname{CHNID}_{(t-i)}+\sum_{j=q+1}^{q+d m a x} \Theta j \operatorname{CHNID}_{(t-j)} \\
& +\sum_{\mathrm{i}=1}^{\mathrm{q}} \varpi \mathrm{i} \mathrm{Y}_{(\mathrm{t}-\mathrm{i})}+\sum_{\mathrm{j}=\mathrm{q}+1}^{\mathrm{q}+\mathrm{dmax}} \varpi \mathrm{j} \mathrm{Y}_{(\mathrm{t}-\mathrm{j})}+\varepsilon_{\mathrm{t} 4}
\end{aligned}
$$

Toda and Yamamoto Granger Causality model specification which used to estimate the impact of UIP on Nigeria and USA interest rate differential on investment in Nigeria is:

$$
\begin{aligned}
& I N V=\mathfrak{v}+\sum_{i=1}^{q} \rho i \operatorname{INV}_{(t-1)}+\sum_{j=q+1}^{q+d m a x} \rho j \operatorname{INV}_{(t-j)}+\sum_{i=1}^{q} \Psi_{i} \operatorname{USNID}_{(t-i)}+\sum_{j=q+1}^{q+d m a x} \Psi j \operatorname{USNID}_{(t-j)} \\
& +\sum_{\mathrm{i}=1}^{\mathrm{q}} \varpi \mathrm{i} \mathrm{Y}_{(\mathrm{t}-\mathrm{i})}+\sum_{\mathrm{j}=\mathrm{q}+1}^{\mathrm{q}+\mathrm{dmax}} \varpi \mathrm{j} \mathrm{Y}_{(\mathrm{t}-\mathrm{j})}+\sum_{\mathrm{i}=1}^{\mathrm{q}} \Pi \mathrm{i} \operatorname{USNCPID}_{(\mathrm{t}-1)}+\sum_{\mathrm{j}=\mathrm{q}+1}^{\mathrm{q}+\mathrm{dmax}} \Pi \mathrm{j} \operatorname{USNCPID}_{(\mathrm{t}-\mathrm{j})}+\varepsilon_{\mathrm{t} 5}
\end{aligned}
$$




$$
\begin{aligned}
& \text { USNID }=\pi+\sum_{\mathrm{i}=1}^{\mathrm{q}} 8 \mathrm{i} \operatorname{USNID}_{(\mathrm{t}-1)}+\sum_{\mathrm{j}=\mathrm{q}+1}^{\mathrm{q}+\mathrm{dmax}} 6 \mathrm{j} \operatorname{USNID}_{(\mathrm{t}-\mathrm{j})}+\sum_{\mathrm{i}=1}^{\mathrm{q}} \theta i \operatorname{INV}_{(\mathrm{t}-\mathrm{i})}+\sum_{\mathrm{j}=\mathrm{q}+1}^{\mathrm{q}+\mathrm{dmax}} \theta \mathrm{j} \operatorname{INV}_{(\mathrm{t}-\mathrm{j})} \\
& +\sum_{\mathrm{i}=1}^{\mathrm{q}} \zeta \mathrm{i} \mathrm{Y}_{(\mathrm{t}-\mathrm{i})}+\sum_{\mathrm{j}=\mathrm{q}+1}^{\mathrm{q}+\mathrm{dmax}} \zeta \mathrm{j} \mathrm{Y}_{(\mathrm{t}-\mathrm{j})}+\sum_{\mathrm{i}=1}^{\mathrm{q}} \text { } \text { i USNCPID }(\mathrm{t}-1) \\
& +\sum_{\mathrm{j}=\mathrm{q}+1}^{\mathrm{q}+\mathrm{dmax}} \text { ij } \operatorname{USNCPID}_{(\mathrm{t}-\mathrm{j})}+\varepsilon_{\mathrm{t} 6} \\
& Y=\mathfrak{h}+\sum_{i=1}^{q} \tau i Y_{(t-1)}+\sum_{j=q+1}^{q+d m a x} \tau j Y_{(t-j)}+\sum_{i=1}^{q} \chi i I N V_{(t-i)}+\sum_{j=q+1}^{q+d m a x} \chi j I^{\prime N V} V_{(t-j)} \\
& +\sum_{i=1}^{\mathrm{q}} \eta \operatorname{USNID}_{(\mathrm{t}-\mathrm{i})}+\sum_{\mathrm{j}=\mathrm{q}+1}^{\mathrm{q}+\mathrm{dmax}} \eta j \operatorname{USNID}_{(\mathrm{t}-\mathrm{j})}+\sum_{\mathrm{i}=1}^{\mathrm{q}} \rho \mathrm{i} \operatorname{USNCPID}_{(\mathrm{t}-1)} \\
& +\sum_{\mathrm{j}=\mathrm{q}+1}^{\mathrm{q}+\mathrm{dmax}} \rho \mathrm{j} \operatorname{USNCPID}_{(\mathrm{t}-\mathrm{j})} \varepsilon_{\mathrm{t} 8} \\
& \operatorname{USNCPID}=\phi+\sum_{\mathrm{i}=1}^{\mathrm{q}} \Omega \operatorname{iUSNCPID}_{(\mathrm{t}-1)}+\sum_{\mathrm{j}=\mathrm{q}+1}^{\mathrm{q}+\mathrm{dmax}} \Omega \operatorname{jSNCPID}_{(\mathrm{t}-\mathrm{j})}+\sum_{\mathrm{i}=1}^{\mathrm{q}} \operatorname{Ui~INV}_{(\mathrm{t}-\mathrm{i})} \\
& +\sum_{j=q+1}^{q+d m a x} \pi j \operatorname{INV}_{(t-j)}+\sum_{i=1}^{q} \psi i \operatorname{USNID}_{(t-i)}+\sum_{j=q+1}^{q+d m a x} \psi j \operatorname{USNID}_{(t-j)} \\
& +\sum_{\mathrm{i}=1}^{\mathrm{q}} \vartheta \mathrm{i} \mathrm{Y}_{(\mathrm{t}-\mathrm{i})}+\sum_{\mathrm{j}=\mathrm{q}+1}^{\mathrm{q}+\operatorname{dmax}} \vartheta \mathrm{j} \mathrm{Y}_{(\mathrm{t}-\mathrm{j})}+\varepsilon_{\mathrm{t} 4}
\end{aligned}
$$

The objectives of this study can be achieved based on the following two econometric techniques which include: ARDL bound test .The ARDL bound test is used to analyze equations (1) and (2) while both ARDL bound test and Toda-Yamamoto causality is used to analyze equations (3) and (4) with E-views software

\section{Presentation and Discussion of Findings}

This study started with unit root test using Augmented Dickey-Fuller (ADF) and various residual test such as serial correlation, heteroskedasticity and normality test were performed to examine the data characteristic to avoid spurious results. The Autoregressive Distributed Lag (ARDL) approach to $\log$ run relationship examines existence of cointegration among the variables. Toda-Yamamoto causality analyzed the effects of interest rate differentials on investment in Nigeria.

\subsection{Unit Root Test Results}

The results of unit root test of the variables under study are displayed in Table 1. The outcome of the ADF on Table 1 shows that variables such as USA and Nigeria interest rate differentials (USNID), USA and Nigeria exchange rate differentials (USNEXD), China and Nigeria interest rate differentials (CHNID), and China and Nigeria exchange rate differentials (CHNEXD),United States of America and Nigeria consumer price index differentials (USNCPID), Investment(INV) and Income (Y) are stationary at first difference while China and Nigeria consumer price index differentials (CHNCPID) is stationary at levels.

In other words, most of the variables like USNID, USNEXD, CHNID, CHNEXD, INV, GDP and USNCPID are integrated of order one, that is I(1) while CHNCPID is integrated of order zero, that is I(0).

Table 1. Augmented dickey-fuller unit root test results

\begin{tabular}{llllll}
\hline \multicolumn{3}{c}{ LEVEL } & \multicolumn{3}{c}{$1^{\text {st }}$ DIFF. } \\
\hline Variables & 5\% critical & & \multicolumn{3}{c}{ critical } \\
\hline USNID & -2.472658 & -3.536601 & -6.015839 & -3.544284 & Remarks \\
\hline
\end{tabular}




\begin{tabular}{llllll}
\hline USNEXD & -1.125496 & -3.540328 & -3.872086 & -3.540328 & $\mathrm{I}(\mathrm{I})$ \\
\hline CHNID & -2.787763 & -3.536601 & -6.105251 & -3.544284 & $\mathrm{I}(\mathrm{I})$ \\
\hline CHNEXD & -1.017754 & -3.540328 & -3.896890 & -3.540328 & $\mathrm{I}(1)$ \\
\hline INV & -3.331487 & -3.548496 & -4.718882 & -3.552973 & $\mathrm{I}(1)$ \\
\hline Y & -1.060384 & -3.544284 & -5.625072 & -3.548490 & $\mathrm{I}(1)$ \\
\hline USNCPID & -1.213348 & -3.540328 & -4.464520 & -3.540328 & $\mathrm{I}(1)$ \\
\hline CHNCPID & -3.996060 & -3.540328 & - & - & $\mathrm{I}(0)$ \\
\hline
\end{tabular}

Source: Computed by the Authors, 2018

\subsection{Autoregressive Distributed Lag (ARDL) Bound Testing Analysis for Nigeria and USA}

Table 2. Lag length selection criteria for the models

\begin{tabular}{llll}
\hline lags & AIC & SBC & HQC \\
\hline 4 & 14.84649 & 15.65457 & 15.12207 \\
1 & $14.46435^{*}$ & $14.73371^{*}$ & $14.55621^{*}$
\end{tabular}

Source: Computed by the Authors, 2018

The lag length selection criteria table above shows that the best lag length for the model is lag one(1) using the maximum lag of four. This so because using AIC and SBC the smallest value is 14.46435 and 14.73371 compared to 14.84649 and 15.65457 of AIC and SBC respectively. This means that the best lag for the model is lag one.

4.2.1 ARDL Bound Testing Estimated Result for USA and Nigeria

The bounds-testing result shows that there is no long-run relationship between USNID USNEXD and USNCPID. The " $K$ " in the result stands for 2 explanatory variables.

Table 3. ARDL bounds test results

\begin{tabular}{lll}
\hline Test Statistic & Value & $\mathrm{K}$ \\
\hline F-Statistic & 2.161163 & 2 \\
\hline CRITICAL VALUE BOUNDS & & \\
\hline Significance & I0 Bound & I1Bound \\
\hline $10 \%$ & 3.17 & 4.14 \\
$5 \%$ & 3.79 & 4.85 \\
$2.5 \%$ & 4.14 & 5.52 \\
$1 \%$ & 5.52 & 6.36 \\
\hline
\end{tabular}

While $\mathrm{k}=$ number of explanatory variables in the test.

Source: Computed by the Authors, 2018

Table 4. The short-run result for Nigeria and USA

\begin{tabular}{lllll}
\hline Variable & Coefficient & Std. Error & t-Statistic & Prob. \\
\hline D(USNEXD) & -0.009061 & 0.019404 & -0.466965 & 0.6436 \\
D(USNCPID) & 0.013926 & 0.017120 & 0.813442 & 0.4218 \\
ECM(-1) & -0.248133 & 0.104814 & -2.367354 & 0.0239 \\
\hline
\end{tabular}

R-square $=0.164208$, F-statistics $=2.161163$, prob(f-statistic $)=0.111289$

Adjusted-R-square $=0.08822$ D.W. $=2.041364$

Source: Computed by the Authors, 2018 
From Table 4, F-statistic of 2.161163 is lower than the lower bound of 3.79 (as well as the upper bound of 4.85) at 5\% level of significance; this shows that there is no long run relationship between that USNID, USNEXD and USNCPID (United State of America and Nigeria consumer price index differentials) proxy for inflation. Thus the theory of UIP does not hold in practice between Nigeria and United State of America (USA). One of the reasons why this theory is not holding between USA and Nigeria may be due to the high disparity in values between US dollars and Nigeria Naira and inefficiency of capital market. The inefficiency in capital market is manifest in asset's prices not always accurately reflecting its true value. Unlike the developed countries, (like USA, China and Russia) with efficient capital market where all publicly available information about stocks are fully reflected in their prices.

4.3 Autoregressive Distributed Lag (ARDL) Bound Testing Analysis for China and Nigeria

The objective of this work is to also examine for the possibility of the theory of UIP between Nigeria and China. The study employed ARDL bound testing approach.

4.3.1 ARDL Bound Testing Estimate for China and Nigeria

The bounds-testing result shows the presence of cointegration among the variables (CHNID, CHNEXD and CHNCPID).

Table 5. ARDL bounds test results

\begin{tabular}{lll}
\hline Test Statistic & Value & $\mathrm{K}$ \\
\hline F-Statistic & $\mathbf{1 2 . 4 0 9 3 9}$ & $\mathbf{2}$ \\
\hline CRITICAL VALUE BOUNDS & & \\
\hline Significance & I0 Bound & I1Bound \\
\hline $10 \%$ & 3.17 & 4.14 \\
$5 \%$ & 3.79 & 4.85 \\
$2.5 \%$ & 4.41 & 5.52 \\
$1 \%$ & 5.15 & 6.36 \\
\hline
\end{tabular}

$\mathrm{K}$ value in the result above stands for 2 explanatory variables used for the test.

Source: Computed by the Authors, 2018

From the result above, 12.40939 is more than the upper bound value of 4.85 and lower bound level of 3.75 . This indicates that there is cointegration between the variables under study which implies that, the theory of uncovered interest rate parity holds in practice between Nigeria and China with china being the anchor country. The implication is that, investors cannot gain an arbitrage opportunity. Thus, Nigeria stands a better chance to benefit from trading with china in the long run. What this means is that, Nigeria and china should be encouraged to trade with each other since Chinese yen being the high value currency compare with the Nigerian naira will depreciate and Nigeria will gain or benefit from trading with china in the long run.

Table 6. Short and long run coefficient for China and Nigeria

Dependent variable CHNID

\begin{tabular}{lllll}
\hline \multicolumn{2}{l}{ SHORT RUN COEFFICIENT } & & & \\
\hline Variable & Coefficient & Std. Error & t-Statistic & Prob. \\
\hline D(CHNEXD) & 0.019380 & 0.017141 & 1.130655 & 0.2675 \\
D(CHNCPID) & 0.768487 & 0.070288 & 10.933446 & 0.0000 \\
D(CHNCPID $(1))$ & -0.136189 & 0.045800 & -2.973544 & 0.0059 \\
ECM(-1) & -0.279896 & 0.060541 & -4.623248 & 0.0001 \\
\hline
\end{tabular}

LONG RUN COEFFICIENT 


\begin{tabular}{lllll}
\hline Variable & Coefficient & Std. Error & t-Statistic & Prob. \\
\hline CHNEXD & -0.030383 & 0.018601 & -1.633436 & 0.1132 \\
CHNCPID & 0.921602 & 0.275649 & 3.343393 & 0.0023 \\
C & 7.242521 & 6.097276 & 1.187829 & 0.2445
\end{tabular}

R-Square 0.868125; Adjusted R-Square 0.840840

F-statistic 31.81752 Prob (F-statistic) 0.00000

Durbin-Watson stat 1.851033

Source: Computed by the Authors, 2018

The F-statistics value of 31.81752 (prob. 0.000) as shown in Table 6 indicates that China and Nigeria exchange rate differentials (CHNEXD) and China-Nigeria consumer price index differentials (CHNCPID) are jointly having significant effect on uncovered interest rate parity (CHNID) in the short run but individually it was only China-Nigeria consumer price index differentials (CHNCPID) that shows significant effects on uncovered interest rate parity (CHNID). China and Nigeria exchange rate differentials (CHNEXD) have weak effect on uncovered interest rate parity (CHNID) within the period of study.

The results from Table 6 shows China and Nigeria exchange rate differentials (CHNEXD) have a positive relationship with uncovered interest rate parity (CHNID) in the short run period but weak effect in the long run. This implies that a $1 \%$ rises in CHNEXD result to $0.19 \%$ increase CHNID within the short run period while $1 \%$ rises in CHNEXD result to $0.30 \%$ fall in CHNID in the long period. $1 \%$ increase in CHNCPID leads to $76.8 \%$ increase in CHNID but at lag 1, a percentage increase in CHNCPID result to $13.6 \%$ decrease in CHNID in short run while in the long run, $1 \%$ increase in CHNCPID, CHNID would increase CHNID by $92.2 \%$. The negative relationship between CHNID and CHNEXD in the long run period confirms the validity of the theory between Nigeria and China which implies that the variables may converge in the long run.

\subsection{ARDL Bounds Testing Analysis of UIP Between USA/ Nigeria and Investment in Nigeria}

In order to assess whether investment (INV), USNID, GDP and USNCPID have long run relationship and also to investigate the effect of theory of UIP on investment Nigeria, ARDL bounds testing and Toda Yamamoto Causality were used for analysis.

4.4.1 ARDL Bounds Testing Estimates for the Relationship Between UIP Between USA/ Nigeria and Investment in Nigeria

Table 7. ARDL bound results

\begin{tabular}{lll}
\hline Test Statistic & Value & $\mathrm{K}$ \\
\hline F-Statistic & 6.657642 & 3 \\
\hline CRITICAL VALUE BOUNDS & & \\
\hline Significance & $\mathrm{I}(0)$ Bound & $\mathrm{I}(1)$ Bound \\
\hline $10 \%$ & 2.72 & 3.77 \\
$5 \%$ & 3.23 & 4.35 \\
$2.5 \%$ & 3.69 & 4.89 \\
$1 \%$ & 4.29 & 5.61 \\
\hline
\end{tabular}

Source: Computed by the Authors, 2018

From the result in Table 7, 6.657642 is greater than the upper bound (I(1) of 4.35 at $5 \%$ level of significance. Its shows evidence of cointegration among the study variables (that is INV, USNID, GDP and USNCPID). 
Table 8. Short and long run coefficient for the impact of UIP between USA and Nigeria on investment in Nigeria Dependent variable: $\log (\mathrm{INV})$

\begin{tabular}{|c|c|c|c|c|}
\hline \multicolumn{5}{|c|}{ SHORT RUN COEFFICIENT } \\
\hline Variable & Coefficient & Std. Error & $\mathrm{t}$-Statistic & Prob. \\
\hline $\mathrm{d}$ (USNID) & -0.000553 & 0.007051 & -0.078499 & 0.9381 \\
\hline d(USNID(-1)) & -0.009591 & 0.006275 & -1.528288 & 0.1390 \\
\hline d(USNCPID) & 0.001040 & 0.001338 & 0.777494 & 0.4442 \\
\hline $\operatorname{dlog}(Y)$ & 0.656580 & 0.518154 & 1.267152 & 0.2168 \\
\hline $\operatorname{dlog}(Y(-1))$ & -0.984751 & 0.506448 & -1.944428 & 0.0632 \\
\hline $\operatorname{ECM}(-1)$ & -0.460745 & 0.107772 & -4.275198 & 0.0002 \\
\hline \multicolumn{5}{|c|}{ LONG RUN COEFFICIENT } \\
\hline Variable & Coefficient & Std. Error & t-Statistic & Prob. \\
\hline USNID & 0.004791 & 0.012231 & 0.391740 & 0.6986 \\
\hline USNCPID & 0.002257 & 0.002863 & 0.788497 & 0.4378 \\
\hline $\log (\mathrm{Y})$ & 1.656158 & 0.377648 & 4.385461 & 0.0002 \\
\hline $\mathrm{C}$ & -22.060078 & 11.509565 & -1.916674 & 0.0668 \\
\hline
\end{tabular}

Source: Computed by the Authors, 2018

However, in the short run all the variables are not statistically significant at $5 \%$ level, while in the long run only income (Y) is statistically significant with positive impact on investment in Nigeria. The theory of uncovered interest rate parity has negative relationship with investment in Nigeria in the short run but a direct relationship with investment in Nigeria in the long run period. This implies that 1 per cent increases in interest rate differentials for Nigeria and USA (USNID) will lead to $0.005 \%$ decrease in investment in the short run, while in the long run, 1 per cent increase in interest rate differentials will lead to 0.047 per cent increase in investment. The short run result is in agreement with apriori-expectation which states that investment and interest rate have an inverse relationship. It should also be noted that the impact of interest rate differentials for Nigeria and USA is not significant in both the short and long run except income (Y) that is significant in the long run. However, inflation (USNCPID) being the control variable has positive impact on investment in the short run and long run respectively. This implies that 1 per cent decrease in inflation would lead to 0.002257 per cent and 0.00104 per cent decrease in investment in Nigeria in both the long run and short run respectively. The relationship between income (Y) and investment is positive both in the short and long run except for the lagged value of income which is negative. This result also agrees with theories which posit that the rise in income will result to rise in investment. This implies that 1 per cent increase in income will leads to 0.65 per cent increase in investment in the short run while in the long run, 1 per cent increase in income will lead to1.65 per cent increase in investment in Nigeria. It should be noted that the theory of uncovered interest rate parity between USA and Nigeria (USNID) is negative on investment in Nigeria in the short run and positive in the long run. But the effect of the theory of UIP on investment is greater in the long run than (0.0048) in the short run (0.0006).

Table 9. Toda and Yamamoto Granger causality results for UIP (USA and Nigeria) on investment in Nigeria Dependent variable: $\log (\mathrm{INV})$

\begin{tabular}{llll}
\hline Regressors & Chi-sq & Df & P.Value \\
\hline USNID & 0.291956 & 2 & 0.8642 \\
\hline Log (Y) & 17.03365 & 2 & 0.0002 \\
\hline USNCPID & 0.991570 & 2 & 0.6091 \\
\hline ALL & 17.93010 & 6 & 0.0064 \\
\hline
\end{tabular}


Dependent Variable: USNID

\begin{tabular}{llll}
\hline Regressor & Chi-sq & Df & P.Values \\
\hline LOG(INV) & 0.430812 & 2 & 0.8062 \\
\hline LOG(Y) & 19.36058 & 2 & 0.0001 \\
\hline USNCPID & 0.158355 & 2 & 0.9239 \\
\hline ALL & 19.61094 & 6 & 0.0032 \\
\hline
\end{tabular}

Dependent Variable: LOG(Y)

\begin{tabular}{llll}
\hline Regressors & Chi-sq & Df & P.values \\
\hline LOG(INV) & 0.660748 & 2 & 0.7187 \\
\hline USNID & 0.666177 & 2 & 0.7167 \\
\hline USNCPID & 0.578744 & 2 & 0.7487 \\
\hline ALL & 1.806730 & 6 & 0.9366 \\
\hline
\end{tabular}

Dependent variable: USNCPID

\begin{tabular}{llll}
\hline Regressors & Chi-sq & Df & P.values \\
\hline LOG(INV) & 2.564178 & 2 & 0.2775 \\
\hline USNID & 0.360987 & 2 & 0.8349 \\
\hline LOG(Y) & 17.87725 & 2 & 0.0001 \\
\hline ALL & 18.60084 & 6 & 0.0049 \\
\hline
\end{tabular}

Source: Computed by the Authors, 2018

From Table 9, investment (INV) as the dependent variable shows that the theory of uncovered interest rate parity (USNID) and inflation rate (USNCPID) do not individually significantly cause investment in Nigeria. But when the causation of the explanatory variables was observed jointly on investment (INV), the result showed a positive and significant level of causation. Also, when USNID is the dependent variable, it can be seen that INV and USNCPID do not cause USNID individually, but only income (Y) that individually causes USNID. But when all the explanatory variables are jointly considered on USNID, the result indicates positive significant level of causation. From the result of the third section of Table 9, causality from explanatory variables to the dependent variable $\mathrm{Y}$ is not significant, either individually or jointly. Also when USNCPID is the dependent variable, INV and USNID do not granger cause inflation differentials between USA and Nigeria individually, but when considered jointly, the explanatory variables have positive significant causation of inflation (USNCPID).

4.4.2 Autoregressive Distributed Lag (ARDL) Bounds Testing Analysis of UIP (China and Nigeria) on Investment in Nigeria

Table 10. ARDL bound testing result for the relationship between UIP between Nigeria and China and investment in Nigeria

\begin{tabular}{lll}
\hline Test Statistic & Value & $\mathrm{K}$ \\
\hline F-Statistic & 6.808338 & 3 \\
\hline CRITICAL VALUE BOUNDS & & \\
\hline Significance & $\mathrm{I}(0)$ Bound & $\mathrm{I}(1)$ Bound \\
\hline $10 \%$ & 2.72 & 3.77 \\
$5 \%$ & 3.23 & 4.35 \\
$2.5 \%$ & 3.69 & 4.89 \\
$1 \%$ & 4.29 & 5.61 \\
\hline
\end{tabular}


Source: Computed by the Authors, 2018

From Table 10, the value of F-statistic of 6.808338 is more than upper bound of 4.35 at $5 \%$ level of significance. Therefore, it is concluded that there is cointegration.

Table 11. Short run and long run coefficient of UIP (China and Nigeria) on investment in Nigeria

Dependent variable: $\log (\mathrm{INV})$

\begin{tabular}{lllll}
\hline \multicolumn{2}{l}{ SHORT RUN COEFFICIENT } & & & \\
\hline Variable & Coefficient & Std. Error & t-Statistic & Prob. \\
\hline Dlog(INV(-1)) & 0.373779 & 0.176911 & 2.112810 & 0.0468 \\
D(CHNID) & 0.057398 & 0.012053 & 4.762249 & 0.0001 \\
D(CHNID(-1)) & -0.038783 & 0.013379 & -2.898751 & 0.0086 \\
D(CHNCPID) & -0.053589 & 0.010617 & -5.047285 & 0.0001 \\
d(CHNCPID(-1)) & 0.035415 & 0.011777 & 3.007180 & 0.0067 \\
Dlog(Y) & 0.329777 & 0.340735 & 0.967838 & 0.3441 \\
Dlog(Y(-1)) & -0.976967 & 0.340815 & -2.866565 & 0.0092 \\
ECM(-1) & -0.862997 & 0.184139 & -4.686663 & 0.0001 \\
\hline LONG RUN COEFFICIENT & & & \\
\hline Variable & Coefficient & Std. Error & t-Statistic & Prob. \\
\hline CHNID & 0.045002 & 0.007954 & 5.657834 & 0.0000 \\
CHNCPID & -0.049414 & 0.007012 & -7.047281 & 0.0000 \\
$\log ($ Y) & 1.123109 & 0.060376 & 18.601810 & 0.0000 \\
C & -6.450417 & 1.850599 & -3.485584 & 0.0022 \\
\hline
\end{tabular}

Sources: Computed By the Authors, 2018

Impact of theory of uncovered interest rate parity between China and Nigeria on investment in Nigeria is greater in the short run than the long run. Income $(\mathrm{Y})$ has a positive and insignificant effect on investment in Nigeria. This result implies that 1 per cent increase in income will increase investment by 0.33 per cent and 1.12 per cent in the short run and long run respectively. Also, 1 per cent increase in CHNID will increase investment by 0.057 per cent and 0.045 per cent in the short run and long run respectively.

Table 12. Results for Toda and Yamamoto Granger causality for the impact of UIP (Nigeria and China) on Investment in Nigeria

Dependent variable: INV

\begin{tabular}{lllc}
\hline Regressors & Chi-sq & Df & P.Value \\
\hline CHNID & 14.11937 & 2 & 0.0009 \\
\hline Y & 22.02338 & 2 & 0.0000 \\
\hline CHNCPID & 11.62716 & 2 & 0.0030 \\
\hline All & 118.0952 & 6 & 0.0000
\end{tabular}

Dependent Variable: CHNID

\begin{tabular}{lllc}
\hline Regressor & Chi-sq & Df & P.Values \\
\hline INV & 4.118998 & 2 & 0.1275 \\
\hline Y & 4.532404 & 2 & 0.1037 \\
\hline CHNCPID & 16.79140 & 2 & 0.0002 \\
\hline All & 19.57589 & 6 & 0.0033 \\
\hline
\end{tabular}


Dependent Variable: Y

\begin{tabular}{llll}
\hline Regressors & Chi-sq & Df & P.values \\
\hline INV & 2.673657 & 2 & 0.2627 \\
\hline CHNID & 1.170557 & 2 & 0.5570 \\
\hline CHNCPID & 0.771598 & 2 & 0.6799 \\
\hline All & 3.755156 & 6 & 0.7098 \\
\hline
\end{tabular}

Dependent variable: CHNCPID

\begin{tabular}{llll}
\hline Regressors & Chi-sq & Df & P.values \\
\hline INV & 8.648848 & 2 & 0.0132 \\
\hline CHNID & 6.932977 & 2 & 0.0312 \\
\hline Y & 2.721493 & 2 & 0.2565 \\
\hline All & 16.45476 & 6 & 0.0115 \\
\hline
\end{tabular}

Source: Computed by the Authors, 2018

From Table 12, the first section where INV is the dependent variable, CHNID, CHNCPID and Y have positive significant causative impact on investment in Nigeria individually. But the joint causation of the explanatory variables on INV shows a positive and significant level of causation.

In the second section of the Table 12, it is discovered that INV and Y have no significant causative impact on CHNID individually but only CHNCPID that individually causes CHNID. When the causative impacts of the variables are jointly considered on CHNID, the result indicates positive and significant level of causation. From the result of the third section, it is obvious that causality flowing from regressor to the dependent variable $\mathrm{Y}$ were not significant when observed individually or jointly. Also when CHNCPID was made dependent variable, INV and CHNID granger cause CHNCPID individually; but when the explanatory variables are jointly considered, they have positive and significant causative impact on CHNCPID. It is only Y that does not granger cause CHNCPID.

\section{Discussion of Findings}

The result for the validity of the theory of uncovered interest rate parity (UIP) between Nigeria and United States of America shows the absence of long run relationship between United States of America and Nigeria interest rate differentials (USNID), United States of America and Nigeria Exchange rate differentials (USNEXD) and United States of America and Nigeria consumer price index differentials (USNCPID). This implies that the theory of UIP does not hold between Nigeria and United State of America (USA). This means that there is an opportunity to make a risk free profit using currency arbitrage or foreign exchange trading. This is so because investors might take the advantage of high value of dollars by using currency arbitrage or foreign exchange arbitrage. Since the theory of UIP does not hold between Nigeria and USA, the implication is that the higher yield currency that is the US dollar will not depreciate in value compared to Nigerian naira. However, as a result of the high disparity between the US dollar and the Nigerian naira in the long run, Nigeria will not benefit from trading with USA dollar because of high value disparity of dollar in relation to naira and also due to interest rate differences between Nigeria and USA. Also inefficiency of capital market might be another reason why the theory of UIP does not hold between Nigeria and USA. However, there are other reasons that may discourage investors from investing in a country such as Political instability, inconsistency in government policy, and insecurity etc. This result is in line with Orji et al (2013) who tested the validity of the theory of UIP between Nigeria and USA, using conventional Ordinary Least Squares (OLS). Orji et al (2013) found that the theory of UIP does not hold between Nigeria and USA.

However, in examining the validity of the theory of UIP between Nigeria and China, the result revealed the evidence of cointegration between China and Nigeria interest rate differentials (CHNID), China and Nigeria exchange rate differentials (CHNEXD) and China and Nigeria consumer price index differentials (CHNCPID). This implies that the theory of UIP holds between Nigeria and China. The implication of this is that investors can not gain an arbitrage opportunity. The reason is because high yield currency such as the Chinese will depreciate in value and the Nigerian naira will appreciate in value which will encourage Nigerian to trade with china and in the long run, have maximum benefit from trade. Findings from this study further demonstrated that investment (INV) in Nigeria, Nigeria - United 
State of America interest rate differentials (USNID), gross domestic product (GDP) and Nigeria-USA consumer price index (proxy for inflation rate (USNCPID) show evidence of long run relationship. The impact of the theory of UIP on investment in Nigeria-USA investment equation reveals that it has a negative insignificant impact on investment in the short run and a positively significant impact on investment in the long run. The ECM is rightly signed which implies that for any shocks or disequilibrium in investment (INV), the speed of adjustment to equilibrium is 86.3 per cent annually.

Concerning Nigeria and China, the result shows that there is long run relationship between investment (INV) in Nigeria, China and Nigeria interest rate differentials (CHNID), that is the theory of UIP, GDP and China and Nigeria consumer price index differentials (CHNCPID). The finding further revealed that, the theory of UIP between China and Nigeria has a positive and significant impact on investment in Nigeria both in the short and long run; but the impact of the theory of UIP has on investment in Nigeria in the long run is greater than the impact in the short run.

The Toda- Yamamoto causality outcome shows that China and Nigeria interest rate differentials (CHNID), China and Nigeria consumer price index differentials (CHNCPID), and GDP, have positive and significant impacts on investment in Nigeria individually and jointly. Therefore, from the findings, it can be deduced that the theory of UIP between China and Nigeria has a greater impact on investment in Nigeria than the impact of the theory of UIP on investment between United State of America and Nigeria

\section{Conclusion}

The study used ARDL approach and Toda Yamamoto causality test to analyse the short and long-run relationship between investment (INV) in Nigeria and UIP for USA and China, income, exchange rate differentials for USA and China and inflation rate differentials for USA and China. Based on the analyses, it is discovered that the theory of UIP does not hold between Nigeria and USA but it holds between Nigeria and China. This could be attributed to high and low disparity in exchange rate respectively between these countries' currencies, market inefficiency, etc. The analyses also show that the theory of UIP has a long run relationship between Nigeria and USA as well as Nigeria and China. Interestingly also, the impact of the theory of UIP on investment is greater between China and Nigeria than the impact of the theory of UIP on investment between USA and Nigeria.

Since the theory of UIP does not hold between Nigeria and USA as a result of high exchange rate parity, this study recommends managed floating system of exchange rate policy. This policy can also be regarded as "competitive devaluations or 'dirty' floating system. Under the managed floating system, interventions may be embarked upon to avoid either excessive exchange rate appreciations (which may undermine international trading competitiveness) or excess exchange rate depreciations (which may increase risk of inflation). Given that UIP significantly impact on investment, monetary authorities in Nigeria should endeavor to reduce domestic interest rate so as to encourage investment both short and long run period. The result should be applied with caution given that the method of analysis (that is ARDL bounds test) does not require a larger sample size that is necessary for the findings to be generalized.

\section{References}

Adrangi, B., Allender, M., \& Raffiee, K. (2003). Emerging markets and uncovered interest rate parity. Atlantic Economic Journal, 31(3), 291. https://doi.org/10.1007/BF02298824

Agenor, P. (2004). Does Globalization Hurt the Poor?. International Economics and Economic Policy. https://doi.org/10.1007/s10368-003-0004-3

Andrew, C. (2010). Uncovering uncovered interest parity during the classical gold standard era, 1888-1905. Motu Working Paper 10-02 Motu Economic and Public Policy Research 2010.

Banerjee, A., Dolado, J., \& Mestre, M. (1998). Error-Correction Mechanism Tests for Cointegration in Single-Equation Framework. Journal of Time Series Analysis, 19, 267-283. https://doi.org/10.1111/1467-9892.00091

Bhargava, V., Dania, A., \& Malhotra, D. K. (2011). Covered interest rate parity among BRIC nations. The Journal of Business and Economic Studies, 17(1), 37-47.

Chinn, M., \& Meredith, G. (2004). Monetary Policy and Long Horizon Uncovered Interest Parity. IMF Staff Papers 51(3), 409-430.

Clark, J. M. (1917). The Accelerator theory of Investment. Journal of Political Economy. 
Deebii, N. (2016). A Panel Data Analysis of the Validity of Uncovered Interest Rate Parity (UIRP) in Selected African Countries. Research in World Economy, 7(2). https://doi.org/10.5430/rwe.v7n2p15

Diez de los Rios, A., \& Sentana, E. (2007). Testing Uncovered Interest Parity: A Continuous time approach. Bank of Canada Working paper 2007-53. https://doi.org/10.2139/ssrn.1018721

Dmitry, V., Vladimir, B., \& Sergey, B. (2017). Testing and interpreting uncovered interest rate parity in Russia. Russian Journal of Economics, 3, 158-173. https://doi.org/10.1016/j.ruje.2017.06.003

Fama, E. (1984). Forward and Spot Exchange Rates. Journal of Monetary Economics, 9, 319338. https://doi.org/10.1016/0304-3932(84)90046-1

Geert, B. (2007). Examined uncovered interest rate parity and the term structure. Journal of International Money and Finance, 26. https://doi.org/10.1016/j.jimonfin.2007.05.004

Haque, M. A. (2014). Trade war with the undervaluation of the Chinese Yen. Journal of I9nternational Business Research, 13(1), 60-70.

Harchaoui, T., Tarkhani, F., \& Yuen, T. (2005). The effects of the exchange rates on investment: Evidence from Canadian Manufacturing Industries. Bank of Canada Working Paper 2005-22.

Hiruni, N. (2016). The Uncovered Interest rate Parity: A Literature Review Imperial. Journal of Interdisciplinary Research (UIR), 2(6).

Ichiro, O. (2011). China's Capital Controls and Interest Rate Parity: Experience during 1999-2010 and Future Agenda for Reforms. Bank of Japan Working Paper Series.

Isard, P. (1991). Uncovered Interest Parity. IMF Working Paper No. WP/91/51. https://doi.org/10.5089/9781451847017.001

Keynes, J. M. (1923). A Tract on Monetary Reform. London: Macmillan.

Kirikos, D. G. (2002). Discrete Policy Interventionsand Rational Forecast Errors in Foreign Exchange Markets: The Uncovered Interest Parity Hypothesis Revisited. International Journal of Finance and Economics, 7, 327-338. https://doi.org/10.1002/ijfe.195

Kissell, R. (2006). The expanded implementation shortfall: Understanding transaction cost components. The Journal of Trading, 1(3), 6-16. https://doi.org/10.3905/jot.2006.644083

Kocenda, E., \& Cerný, A. (2017). Elements of Time Series Econometrics: An Applied Approach. Karolinum Press.

Lily, J. (2011). Empirical Testing on Uncovered Interest Rate Parity in Malaysia. Journal of Applied Finance \& Banking, 1(2), 95-114. https://doi.org/10.1016/S2212-5671(12)00063-9

Mankiw, N. G. (2000). Macroeconomics (4th ed.). By worth publishers manufactured in the United State of America, LCC card NO. 99-22254.

Marshall and Fisher. (1930). Theory of Interest Rate Determination. Online library of liberty, New York Macmillan. Retrieved September 10, 2019, from https//oll.libertyfund.org

Mehl, \& Cappiello. (2007). Uncovered Interest Parity at Distant Horizons: Evidence on Emerging Economies and Non-linearities. European Central Bank Working Paper Series no.801.

Meredith, G., \& Ma, Y. (2002). The forward premium puzzle revisited. IMF Working Paper WP/02/28. https://doi.org/10.5089/9781451844672.001

Muhammad, O. (2013, March). Does Uncovered Interest Rate Parity Hold After All? University of Groningen, the Netherlands De Nederlandsche Bank. Amsterdam, the Netherlands CESifo, Munich, Germany SBP Working Paper Series No. 57.

Narayan, P. K. (2004). Reformulating critical values for the bounds F-statistics approach to cointegration: an application to the tourism demand model for Fiji. Department of Economics Discussion Papers No. 02/04, Monash University, and Melbourne, Australia.

Nguyen, V. H. (2015). How China to U.S. Foreign Exchange rate relates to U.S. Interest rate and Bank Loans. Global Journal of Business Research, 8(4).

Orji, A., Orji, O., \& Ani, E. G. (2013). Does the Theory of Uncovered Interest Parity Hold for Nigeria?. European Journal of Business and Management, 5(15). 
Özcan, K. (2012). Does Uncovered Interest Rate Parity Hold in Turkey?. International Journal of Economics and Financial Issues, 2(4), 386-394.

Pesaran, M. H., Shin, Y., \& Smith, R. J. (2001). Bound Testing Approaches to the Analysis of Level Relationships. Journal of Applied Econometrics, 16, 289-326. https://doi.org/10.1002/jae.616

Peter, I. (2006). Examined uncovered interest rate parity. International monetary fund IMF Working Paper WP/O6/96.

Phillips, P. C. B., \& Perron, P. (1988). Testing for a Unit Root in Times Series Regression. Biometrica, 75, 335-446. https://doi.org/10.1093/biomet/75.2.335

Redeckaite, A., \& Sokolovska, J. (2004). Testing Uncovered Interest Parity in Latvia. SSE Riga Working Paper, 9(64).

Ronald, A. C., Ramfrez-Rodan, N. R., \& Marco, E. T. (2018). Uncovered Interest Rate Parity and Economic Uncertainty. Department of Economics, Universidad del Pacifico. A Salaverry 2020, Lima 11, Lima, Peru.

Sahil, A. (2013). Uncovered Interest Rate Parity Puzzle in the Foreign Exchange Market. New York University.

Su, C.-W., Wang, K.-H., Tao, R., \& Lobont, O.-R. (2019). Does the covered interest rate fit for China?. Economic Research-Ekonomska istra Zivanja, 32(1), 2009-2027. https://doi.org/10.1080/1331677X.2019.1642780

Tang, K. B. (2011). The Precise form of Uncovered Interest Parity: A Heterogeneous Panel Application in ASEAN-5 Countries. Economic Modelling, 28, 568-573. https://doi.org/10.1016/j.econmod.2010.06.015

Utomi, P. (2007). China and Nigeria. Retrieved from http://csis.org/files/media

Wang, W. (2006). Stochasticity, Nonlinearity and Forecasting of Stream flow Processes.

World Trade Organization. (n.d.). China - WTO Statistics Database.

Wuhan, S., \& Adnan, K. (2013). The effect of interest rate on investment; Empirical evidence of Jiangsu Province, China. Journal of International Studies. 